MedieKultur | Journal of media and communication research | ISSN 1901-9726

Article - Theme section

\title{
The look of aging: \\ Agelessness as post-feminist cool? \\ The aging female CEO in contemporary US TV series
}

\section{Anne Jerslev}

MedieKultur 2017, 63, 67-84

Published by SMID | Society of Media researchers In Denmark | www.smid.dk The online version of this text can be found open access at https://tidsskrift.dk/mediekultur

\begin{abstract}
Recently, older women have started becoming more visible in the media: in film, on television, and in fashion and beauty ads. Taking as my case the representations of the ageing woman as successful CEO in three recent US television series, I address the kind of visibility that is embodied by the older female character in contemporary media. Drawing on discussions of ageing and the female body from cultural gerontology and cultural studies as well as theoretical discussions and empirical studies of representations of ageing women in film and television, I address the notions of agelessness and age appropriateness in relation to the three female CEOs and ask whether the characters represent alternative media images of the older female or merely a new form of ageism.
\end{abstract}

\section{Introduction}

It has been argued that older women have recently become more visible in the media, in film, on television and in fashion and beauty ads (Fairclough, 2012; van den Bulck, 2014; Jermyn \& Holmes, 2015, Jerslev, 2017). Kirsty Fairclough, thus, claims that 
youth now appears to stretch out farther into middle age than ever before. To this end, there has been both an intensification of the visibility and sexual objectification of the older woman in popular culture, particularly on US and UK television (2012, p. 92).

The same could be said of film in which a host of powerful ageing actresses are prominently embodying a variety of female characters (in the US and UK but also outside English-speaking countries such as France and smaller nations like Denmark). The fact that women in the industry have been lobbying politically to get more women in general and more older women in particular into film and television (Whelehan, 2013) has also contributed to the increased visibility of older characters.

By contrast, 10 years ago, Kathleen Woodward (2006) famously claimed that the older female body is made either invisible or hypervisible in visual culture, meaning that, if the older woman is portrayed at all, her image solely denotes old age. Woodward calls this logic "the youthful structure of the look", i.e., "the culturally induced tendency to degrade and reduce an older person to the prejudicial category of old age" (Woodward, 2006, p. 164). However, in recent years, invisibility has gained a broader meaning. Now, invisibility does not only refer to a lack of representations of older women in the media or mean that older female characters are always played by actresses of a much younger age; it also refers to the invisibility of bodily signs of ageing in representations of older women.

Broader explanations for the change in the degree of visibility of older women in popular culture have been linked to the general social-material changes of the ageing population, which since the late 1990s have crystallised into the (much-debated) term "successful ageing" (Rowe \& Kahn, 1997; Katz \& Calasanti, 2015) and the (also muchdebated) idea of "the third age" (Gilleard \& Higgs, 2000; Marshall \& Rahman, 2014), characterised by agency, activity and consumption in contrast to "the fourth age's" more pronounced sense of physical and psychological decline. As such, the third ager is constructed as "fit, fashionable, flexible, functional" (Marshall \& Rahman, 2014, p. 11), seemingly "growing older without ageing" (Katz, 2009, pp. 188-202); along the same lines, Julia Twigg claims that "successful ageing in modern consumer culture is ageing without giving the appearance of doing so" (Twigg, 2013, p. 116). This idea has resonated in particular with the increased spending power of retired people (see, for example, Gilleard \& Higgs, 2000; Higgs \& Gilleard, 2006), and the third-ager's life of relaxation and consumption has been epitomised by the image of post-retirement heterosexual happiness - the laughing youthful couple walking on the beach, clad in matching, brightcoloured attire, their abundant grey hair blowing in the wind. Hence, as pointed out by Gilleard and Higgs, "third-agers, while acknowledging old age, are likely to prefer to live at a considerable physical and psychological distance from it" (Gilleard \& Higgs, 2000, p. 45).

The idea of successful ageing as connected with a youthful lifestyle and an air of "never to visibly age at all" (Etcoff, 1999, p. 112; cf. also Andrews, 1999, p. 305), thus, seems to supersede actual physical and psychological changes in old age. This denial of ageing has been a recurrent critique of third age ideology. However, even if the increased visibility 
of older women in popular culture favours a norm of ageless ageing, representations of older women in film and television do take on a variety of appearances besides tasteful heterosexual relaxedness and post-retirement activity.

Accordingly, taking representations of the ageing woman as a successful CEO in three recent US television series as my case studies, I shall examine the looks of ageing. The selected TV series prominently feature ageing actresses. In HBO's The Newsroom (2012-2014), Jane Fonda (b. 1937) plays Leona Lansing, CEO and owner of a large media corporation. Bernadette Peters (b. 1948) plays Gloria, president of the New York Symphony Orchestra in Amazon's half-hour series Mozart in the Jungle (2014-) and, finally, Christine Baranski (b. 1952) is Diane Lockhart, a name partner in a large Chicago law firm in The Good Wife (CBS, 2009-2016).

\section{The series}

The Newsroom (created and written by Aaron Sorkin) is about the idealistic and hardworking journalistic staff on a news programme called News Night, owned by Leona Lansing, and their struggle to produce serious investigative journalism. Sometimes, they are in opposition to the powerful and controlling CEO, but basically Leona is on their side. Mozart in the Jungle (developed by Roman Coppola, Jason Schwartzman and Alex Timbers) is a web-based comedy-drama series about the relationships between the members of the fictitious New York Symphony Orchestra, its young, creative, charming, but uncontrollable conductor and the older sacked conductor. As the CEO, Gloria has to mediate the different interests and keep the aggressive chairman of the board at bay in order to support the orchestra's creative vision while also trying to make it a profitable business. Finally, in the long-running The Good Wife (created by Robert and Michelle King), the extremely competent Diane Lockhart, senior partner and co-founder of a Chicago law firm, struggles through all seven seasons to keep the firm afloat through its many financial ups and downs. She also struggles with the other partners, with the young female associates who are not as dedicated to (overtime) work as she is, and with the character in the title role, Alicia Florrick, whom Diane offered to mentor when Alicia joined the firm. Along the way, Diane receives flattering offers to advance within the judicial system, but each time she ends up going back to her firm.'

Accordingly, the three older female characters are not retired and, therefore, do not subscribe to the prevalent image of successful ageing as active post-retirement. However, Leona, Gloria and Diane may be representative of a complementary notion of successful ageing as independence, deferred retirement and a period of continued, fulfilling work for women. Moreover, the three characters may be regarded as representative of a growing societal tendency for women to occupy CEO positions (e.g., Vecchio, 2002; Eagly \& Carli, 2003; Lips \& Hastings, 2012), and for this group, the question of retirement may not be as pertinent, for example, as for white-collar workers. 
The Good Wife, in particular, touches on questions of female leadership and the difficulties female CEOs face in a male-dominated work environment. Moreover, the series shows that Diane's feminist attitude to female collaboration and solidarity may not correspond with the attitudes of the younger female associates. A narrative thread in The Good Wife deals with age and ageism in the firm. However, even though a range of studies have shown that female employees in particular have experienced ageism and felt the pressure to maintain their youthfulness (cf., for example, Clarke \& Griffin, 2008), a target of ageist jokes is a male senior partner, Howard, who in one episode (season 7, episode 3) even contemplates suing his firm for ageism. In The Newsroom, there is a discreet, selfironic meta-commentary by Leona Lansing on Leona's/Fonda's made-over body; and, in Mozart in the Jungle, the ageing first oboist Betty exclaims, "Growing old is full of shit; growing old alone is the best" (season 1, episode 5); likewise, Gloria replies to an older woman who describes Gloria as her oldest friend: "If I have to be an oldest something, I'm happy to be your oldest friend" (season 2, episode 7). Otherwise, there are almost no references to age and ageing, and discourses of ageing as such do not "haunt" (Whelelan, 2013, p. 81) the narratives.

It seems clear that these characters break away from the stereotypical role often given to ageing actresses occupying the position of "older women" in the media (cf. Wearing, 2007; van den Bulck, 2014; Bardo, 2014; Dolan, 2013). Furthermore, they do not subscribe to what Josephine Dolan (2013) has called "chronological decorum" or to Julia Twigg's description of normative beauty practices in later years, which are aimed at producing "an acceptable form of woman": "still feminine, still displaying engagement with the disciplinary practices of femininity, yet in a toned-down way that accepts the lesser claims to attention and regard" (Twigg, 2013, p. 18). Therefore, since the series go to great lengths to avoid using the characters merely to signify old age, as Woodward (2006) puts it, the question is: what kind of older woman do they imagine and what replaces toned-down femininity?

Bringing the additional terms age appropriateness and agelessness (Andrews, 1999; Twigg, 2013) into the discussion of the three female characters, I would argue that two different views of how the series portray the older woman can be adopted. On one hand, the series extend the boundaries of audio-visual representations of the older woman, shown through the foregrounding of agency, power, independence and sexuality. The older woman, then, embodies what Chris Gilleard and Paul Higgs have called the "new ageing" in which "ageing and agedness have become less easily read off the body" (Gilleard \& Higgs, 2013, p. 30). Moreover, the ageing female CEO in these series may be regarded as embodying a post-feminist sensibility (Gill, 2007; Gill \& Scharf, 2011; Fairclough, 2012) to the extent that the focus is on a groomed, disciplined body that exudes a powerful, independent femininity. Hence, the series challenge the logic of "acting one's age" (Russo, 1999) and offer alternative representations of the ageing female in which toned-down age appropriateness (Wearing, 2007; Twigg, 2013) does not apply but, rather, is replaced by 
the slim body's display of agency, individuality and self-conscious "to-be-looked-at-ness" (Ticknell, 2011). On the other hand, the lack of references to ageing raises the question of whether these series, in fact, construct a new form of ageism in which a norm of ageless ageing is promoted. And, yet, there may be more to the characters' agelessness than a mere disavowal of ageing and "passing" for younger (Andrews, 1999). I propose that these three popular cultural series challenge the latent ageism in post-feminism (cf. McRobbie, 2007; Whelehan, 2013; Gwynne \& Muller, 2013; Dolan, 2013) and, instead, offer an image of post-feminist ageing.

As a cultural sensibility (Gill, 2007), post-feminism's subject is the young woman, who is understood as "autonomous, agentic and empowered" (Gill \& Scharff, 2011, p. 9). Postfeminism has, thus, been constituted as a generational feminism which took sharp issue with the "old", second-wave feminism's understanding of women as victims of patriarchy (cf. Hua, 2009) and its politics of collective opposition. Tasker and Negra argue that

postfeminism is [...] characterized by a double discourse that works to construct feminism as a phenomenon of the past, traces of which can be found (and sometimes is valued) in the present; postfeminism suggests that it is the very success of feminism that produces its irrelevance for contemporary culture (Tasker \& Negra, 2007, p. 8).

In opposition to the "old" feminism, "popularly portrayed as outmoded" (Whelehan, 1995, p. 240) and embodied by older "unattractive and embittered" feminists (McRobbie, 2009, p. 157), post-feminism does not understand feminism as a political movement and, instead, has at its centre a female subject who is constituted as empowered, individualized and sexualized; conversely, post-feminist discourses have been regarded as a backlash by feminist writers - most prominently, Susan Faludi (see Whelehan, 1995).

Rosalind Gill suggests that, as a kind of generational sensibility, post-feminism is defined by

a shift from objectification to subjectification in the ways that (some) women are represented; an emphasis upon self-surveillance, monitoring and discipline; a focus upon individualism, choice and empowerment; the dominance of a 'makeover paradigm'; a resurgence of ideas of natural sexual difference; the marked 'resexualization' of women's bodies; and an emphasis upon consumerism and the commodification of difference (Gill, 2007, p. 149).

Post-feminism, thus, celebrates individual empowerment and agency; post-feminism insists on the display of sexuality as a sign of individuality and bodily control.

Drawing on this description of post-feminism and theoretical discussions of ageing and the female body from cultural gerontology and cultural studies and applying theory and empirical studies of representations of ageing women in the media, I will expand on these questions of the "looks" of ageing in the sections to follow. The next section goes through a range of quantitative studies of representations of older women in film and 
television from the past decades, which unanimously document the invisibility of older female characters and actresses. After this, I turn to the three series and their female CEOs. I focus on the series' construction of a powerful, independent older woman and the staging of to-be-looked-at-ness in relation to the ageing female body. Even though age is not mentioned, I propose that the series be included in the debates about ageing and "looking one's age" that are found in, for example, gossip sites, where a normative gaze continuously scrutinizes Fonda, Peters and Baranski. Finally, in the last section, I problematize the construction of agelessness as merely ageist: I apply the notion of cool and propose that a cool sensibility may confer an edginess upon representations of the ageing body, which challenges the idea of agelessness as a norm of ageing appropriately.

\section{Invisibility and hypervisibility}

Although realised in different ways, the three female CEOs are all portrayed as independent, powerful and sexual "post-feminist heroines" - to borrow a term from Tasker and Negra (2007). As such, they are representative of a quantitative change not only in the visibility of older women but also in the degree and kind of agency.

Over the past few decades, a range of quantitative studies has examined representations of men and women of different ages in film and television programmes from the 1960s onwards. Most of these studies have concluded that older characters have been severely underrepresented in film and television fiction (compared to other age groups) but also in magazines and advertisements (cf. Williams, Wadleigh \& Ylänne, 2010; Baumann \& de Laat, 2012) and misrepresented in comparison to the distribution of older men and women in the US population.

Signorielli and Bacue (1999) found that there had been no significant change in representations of older people from the late 1960s through the 1990s; and, even though Barrett, Raphael and Gundersson (2014) conclude more recently that older people are not as invisible as they used to be, they also point out that they are still underrepresented.

Traditionally, older women have been underrepresented relative to older men in film and television. Moreover, older female characters have been represented as older at a much younger age than male characters, and, correspondingly, they have been represented as much older than male characters of the same age (Signorielli, 2001, 2004; Lauzen \& Dozier, 2005; Lauzen, Dozier \& Rayes, 2007; Barrett, Raphael \& Gundersson, 2014; Women's Media Center, 2014, 2015; Lauzen, 2016). Finally, in the wake of the seminal study by Gerbner et al. (1980) of the misrepresentation of older people in the media, a range of studies has shown how negative representations of older people not only influence general attitudes toward older people but also older people's self-perception (for an overview, see Barrett, Raphael \& Gundersson, 2014).

It can be difficult to compare the different studies for a number of reasons: first, they tend to focus on either film or television (particularly, prime time television but also, more 
recently, on comparisons between broadcast, cable and digital shows (cf. Women's Media Center, 2015)); second, they use different data collection methods; third, they break down age into measurable categories in different ways; and, fourth, they tend to focus on different genres. Despite these differences, however, it seems that, to a large extent, what Gerbner et al. found in 1980 still holds true. Moreover, it seems that Woodward's notions of invisibility and hypervisibility regarding representations of older women also hold true (Woodward, 2006).

As for invisibility, Signorielli (2004) shows that only $1.7 \%$ of female characters in prime time television during the 1990s were 65 or older (compared to women aged $35-49$ years old, who made up $37 \%$ of the characters but made up only $14 \%$ of the total female population). Moreover, Lauzen and Dozier (2005) found in their 2002 study of representations of different age groups in top-grossing films that women over the age of 60 made up $8 \%$ of characters but $22 \%$ of the entire population (in contrast, women aged 30-39 made up $32 \%$ of film roles but only $18 \%$ of the US population); in addition, in the 2004 study by Lauzen, Dozier and Rayes (2007), women accounted for $26 \%$ and men $74 \%$ of characters over 60 in prime time television. Most recently, in "The Status of Women in the Media 2014 Report", female characters over 65 made up only $3.7 \%$ of all characters in the top-grossing films from 2012.

Regarding hypervisibility, the studies show that older women tend to be portrayed primarily as "old" (Signorielli, 2004). In contrast to their male counterparts, women barely over 50 were characterized as older in the study of women in television in the 1990s (Signorielli, 2001); and, to a greater extent than men, older women were referred to as old. Moreover, in comparison with male characters, female characters over 60 occupied more passive positions (cf. Signorielli, 2001; Lauzen, Dozier \& Rayes, 2007): they were less likely to work outside the home; and, if they were, their occupation was not mentioned as often. They were portrayed as exercising less occupational power than male characters ( $25 \%$ of female characters vs. $50 \%$ of male characters), and they were portrayed as exercising less leadership (20.6\% of male characters in contrast to only $8.3 \%$ of the female characters (Lauzen, Dozier \& Rayes, 2007, p. 351). Thus, the general picture with respect to representations of older men and women in popular film is, as argued by Lauzen and Dozier (2005), that older female characters are not portrayed as goal-oriented: "Whereas male characters of all ages were likely to have goals, female characters were less likely to have goals as they aged. These portrayals imply that men have tasks to accomplish in the world, regardless of age" (Lauzen \& Dozier, 2005, p. 444).

"The Status of Women in the US Media 2014" report concluded that not much has changed since 2002. Women are still much younger than men, and they are severely underrepresented as protagonists as well as in other roles. However, the report also noted that women had more roles on cable than on network television; along the same lines, the corresponding 2015 report showed that the share of roles for women was somewhat larger on shows produced for digital platforms than for cable. These recent 
reports, however, do not go into very much detail regarding age differences. In spite of this reservation, because of the increased tendency to target more demarcated audiences or age groups both on cable and digital platforms, it might very well be that both the limited number (invisibility) and the more unfavorable representations of older men and, particularly, older women (hypervisibility) documented throughout the studies I have mentioned here are in the process of changing. ${ }^{2}$

In her article in Postfeminism and Contemporary Hollywood Cinema, Imelda Whelehan (2013) argues that films with older female protagonists are still rare, and the prominence of some older female stars (such as Meryl Streep, Susan Sarandon, Diane Keaton and Jessica Lange in the US and Helen Mirren, Judy Dench and Maggie Smith in the UK) are exceptions to the rule. She also claims, however, that their stellar careers have provided them with the power to influence the creation of roles that address ageing in a nuanced way and challenge normative ideas of chronological decorum. In the following section, I will move on to discuss how the three female characters in The Newsroom, The Good Wife and Mozart in the Jungle challenge normative representations of ageing femininity or what Cornel Sandvoss has called "the restrictive shell of later life" (Sandvoss, 2014, p. 210).

\section{Representations of the ageing female CEO}

In Mozart in the Jungle and The Newsroom, questions of age and ageing are only hinted at, whereas, in The Good Wife, differences of opinion between members of a younger and an older generation are more pronounced. In The Good Wife, problems of age and age anxiety are particularly attached to the male senior partner, Howard, who is the victim of ageist bullying by the younger partners in the firm and who, at one point, confesses that, "old age hurts". In Mozart in the Jungle, Gloria's opponent on the board of the NY Symphony Orchestra, the younger Edward Biben, diets and exercises excessively, while Gloria, apparently many years his senior, effortlessly displays her shapely body in tight, low-cut dresses whether at work or at parties. Gloria never wears jackets in contrast to Leona and Diane, who appear in more business-like attire while still retaining their femininity; Gloria and Diane wear large, conspicuous necklaces with their mostly monochrome dresses. As such, they all exude confidence, independence and an exclusive to-be-looked-at-ness and are anything but the toned-down, self-effacing older woman about which Julia Twigg (2013) writes. For example, when Gloria has her office redecorated, she asks advice as to which curtain fabric "sets off my complexion better" (season 2, episode 1) - while a medium close-up frames her face against the background of different fabrics, her tight green dress all the while emphasizing her body shape.

Whereas Biben and Gloria are meant to represent two different generations (Brennan Brown, who plays Biben, was born in 1968 and Bernadette Peters in 1948), it is hard to really see any difference in age between the two. Gloria's appearance is emphasized 
throughout the series by Biben's recurrent, casual compliments on her fabulous looks, by her sensuality, and by her dress code but also by the cultural clash between Biben's irritating childishness and Gloria's self-confident coolness and consideration. It is implied that Biben's childish behaviour reflects his inability to make well-considered decisions as chairman of the board. In contrast, Gloria's effortlessly disciplined body signifies her power.

Unlike Gloria, The Newsroom's Leona Lansing has a grown-up son, whom she appoints president of her media corporation without actually delegating any power to him. Leona is in charge; she is in control of herself and others and is fully aware of her value and charisma. We see her sitting in the back of a conference room during discussions about the news programme, listening impatiently to the men and then reducing them to silence by exclaiming that they are all idiots. Or we see her diligently using her cell phone and iPad, always within reach. Leona uses sarcasm and irony effectively; she is portrayed as frank and brash but also charming and smart.

Leona's independence and self-confidence, her passion for her news channel and her ability to attract the admiring attention of others is particularly brought out in a scene (season 2, episode 7) in which she comes fresh and excited from a fundraising party late in the evening to meet with her newsroom staff, who have decided to resign because of what they regard as a failure to live up to journalistic ethical standards. The scene starts with the three News Night journalists waiting for her and worrying that they have dragged her out of bed - implying that an old lady is in bed at this time of night. Actually, the scene is mostly about Leona's turning their prejudices about old age upside down. At first, her aggrieved voice is heard off-screen, saying "You did not get me out of bed tonight", and there is a cut to a medium close-up of Leona dressed in an exquisite evening gown; she continues, "I just paid a thousand dollars to see Skyfall and attend a party at the Museum of Modern Art". The reason, she says as a matter of course, was to meet Daniel Craig, who, to her great disappointment, did not make it due to bad weather. The camera follows Leona in medium close-up wandering around the room, filling the space with her high-spirited talk and her body, while her three employees sit silently and a bit hunched up. She refers to herself as the smartest person in the room; at one point, she looks at her reflection in a window, reorganizes her hair, and exclaims complacently, "my makeup lasts a long time" - perhaps, a meta-commentary on the actresses "made-up" face. She mocks the three staff members for giving up and tells them in no uncertain terms that "you will resign when I fire you". Arms akimbo, she orders them harshly to stop pitying themselves and just start working on winning back the trust from the public they claim to have lost.

In the final episodes of The Good Wife, Diane Lockhart is working to realize her vision of a profitable all-female law firm. She considers corporate networks to be gender-biased. Therefore, she encourages the young women in the firm to seek her help as, in the pilot episode, when she tells the new associate Alicia, "I want you to think of me as a mentor, Alicia. It's the closest thing we have to an old boys' network in this town: women helping 
women". However, The Good Wife is ambivalent about the merits and difficulties of creating and maintaining female friendships (cf. Garber, 2016). The implication is that Diane's vision of a workplace sisterhood may be more a child of her own generation's "second wave" feminism and work identity than the younger generation's more individualized career management. Whereas Diane has no children and mostly prioritises her work over her love life, her younger female colleagues see no problem in choosing to be a full-time mother for a while and afterwards resuming their career. To Diane's bewilderment, one of the junior associates resigns when she becomes pregnant - but returns to another law firm fully in control of her career in a later season. Moreover, the young women make it clear that they do not need mentoring. The Good Wife presents a range of intelligent women of different ages in important positions; it shows that Diane's vision of collective sisterhood is hard to realize and may be overcome by a different postfeminist individualism embodied by the younger lawyers, who seem to have no difficulty employing their youth and femininity to strategic ends. However, the series' emphasis on Diane's slender body, her cool femininity and her power ensure that these differences of opinion do not construct her either as old or outdated. ${ }^{3}$

\section{The ageless body and norms of age appropriateness}

Leona Lansing, Gloria and Diane Lockhart are represented as powerful heroines, exuding a self-confident air of ageless to-be-looked-at-ness. As such, they are in possession of what Dolan (2013) has called the "embodied firmness" of successful ageing. In contrast to the young women surrounding them, they signal power and success in the business world through their slim bodies.

Many scholars have discussed the female body's ageing characteristics, how the thin, toned, shapely body denotes youthfulness in contrast to the typical ageing female body, which has, for example, gained weight around the waist (cf. Twigg, 2013; Clarke, 2011, p. 21-23). Moreover, they have pointed out how contemporary culture persistently advocates dress norms appropriate for the ageing female: the avoidance of dramatic styles or colours and the use of "quieter, more sober and self-effacing forms" (Twigg, 2013, p. 27). In stark contrast to this look of ageing, all three women in the TV series display a carefully-arranged, conspicuous look. The emphasis is on a slender body dressed in tight and shapely feminine attire, and close-ups of faces confirm the agelessness signified by the bodies. The series confirm - particularly, with regard to older women - that " $t]$ oday, a sleek toned, controlled figure is normatively essential for portraying success" (Gill, 2007, p. 150). In that way, the women's powerful positions are confirmed and authenticated by means of their slim appearance.

Moreover, the construction of the series' perception of ageing is underpinned by gossip sites' persistent discussions of the actresses' youthful looks. All three actresses have been targets of "hyper-scrutiny" (Fairclough, 2012; Van den Bulck, 2014) on celebrity 
cosmetic surgery sites, and series of before-after images have been posted over the years. Whereas Fonda's cosmetic operations are no secret, gossip stories about Baranski and Peters centre around the question "did they?" or "didn't they?" have anything "done" to their face.

Normative conceptions of "looking one's age" flourish when gossip sites scrutinise celebrities' looks. For example, the celebrity gossip site plasticsurgerytalks.com says of Christine Baranski that, "plastic surgery has been a subject of speculation for years", and "it seems slightly heavy to digest that there has been no role of Botox or skin tightening procedures in her much-appreciated youthful appearance for years, irrespective of her age". ${ }^{4}$ Similarly the gossip site celebritypost.net asks about Baranski in a rhetoric typical of gossip sites, disguising rumour as factual information (Jerslev, 2010): "Why the Plastic Surgery Claim?"5 Supporting its own claim with so-called expert statements, it answers:

Christine Baranski is said to have gone through series of plastic surgery because she actually looks younger than her age. The famous actress is now in her early 60 s. She ought to be aging like her mates. Yet, there are no wrinkles noticed on her body. Her face is still glowing like that of a young lady. This is why many of her fans believe she must have gone under the surgeon's knife.

Moreover, the site informs that, "confronted" about her appearance, Baranski merely points to a healthy lifestyle. Nevertheless, the site insists: "Despite her claims, experts still believe she must have had one kind of plastic surgery or the other. She can't be looking so young at age 60". Accordingly, it categorically states, "Christine Baranski is [sic] yet to admit she had a plastic surgery".

Fairclough (2012) suggests that gossip sites assess female celebrities' appearance based on three categories: "the gruesome" (celebrities who have had bad surgery and are assessed as awful), "the desperate" (celebrities who are presumed to have had surgery in order to maintain a career and who are slightly ridiculed) and "the sanctioned" (celebrities who are praised for successfully having had plastic surgery, which has helped them maintain a youthful look). However, I suggest that both Christine Baranski and Bernadette Peters belong to a fourth category in which the vague doubt about procedures underlying "sanctioned" stories is brought to the fore: 'They did probably - and why not admit it and share it with fans?' Hence, the articles about Baranski argue paradoxically that the "natural" process of ageing gracefully can only succeed with the help of plastic surgery. Unsurprisingly, the article validates its own claim by assessing Baranski's surgery as "sanctioned", concluding that "we are more than delighted by the result".

Along the same lines, gossip sites have discussed whether Bernadette Peters' flawless complexion is natural or acquired through cosmetic surgery. The scrutinizing gaze is passed on to an expert in the article "Is it good plastic surgery or good genes?" In a similar way, "Bernadette Peters Plastic Surgery - a Perfect Look at Old Age" scrutinizes the actress's face and neck, bit by bit. It speculates hyperbolically: 
This is the question that most people ask of the Grammy awards nominee. She has denied any link and speculation that suggest that she had plastic surgery. In fact she claims that anything that disturbs her skin or appearance is not tolerated. People including nutritionists, gossip columnists and a section of her fans have found it difficult to buy into this story

- and then offers a range of "proofs" of the ways "it can be concluded that Bernadette Peters' plastic surgery has done so much to save her looks from the effects of aging" (my italics). The youthfulness hailed on cosmetic surgery gossip sites is, thus, normatively constituted as age-appropriateness (because ageing is a horrible thing, one is obliged to do something to conceal it).

As if in opposition to gossip sites' affronting "hyper-scrutiny", there is a remarkable ultra-close-up of Gloria's red lips in Mozart in the Jungle when she performs the suggestive "Come On-A My House" at an open mike club (season 2, episode 4). She is dressed in a black, tight, low-cut and sleeveless dress, which shows off her toned arms, while backlighting emphasizes her slim body and her voluptuous red curls. The ultra-close-up, which accentuates as well her red lips as the lines around her mouth and on her chin, add to the impression that the scene may be regarded as challenging gossip sites' normative gaze; in a sense, the series permits Peters to orchestrate the gaze through her character.

When it comes to Leona Lansing in The Newsroom, it is part of Fonda's celebrity persona to be open and self-ironic about her procedures. In 2011, for example, she wrote in a post on her blog that

Bob Evans complimented me on my new, short haircut and I said, "Thanks. I just had some 'work' done on my chin and neck and had the bags taken away from under my eyes so I decided it would be good to get a new hair cut so people will think it's my new hair. ${ }^{8}$

The same kind of coolness is attached to Leona through the character's self-confident self-display, the way she rebukes everyone around her, her attachment to props such as sunglasses and, not least, her diligent use of digital accessories such as her smartphone and tablet. Obviously, Leona is portrayed as cool, and I suggest that cool - although in different ways and to different degrees - is a suitable term for describing the way the series construct the female CEO's look of ageing and, hence, contributes to the staging of what I would call a post-feminist agelessness - which does not refuse ageing but challenges notions of age appropriateness.

Cool is an edgy aesthetic sensibility, a self-confident visibility and an anti-sentimental position exuding individualism and detachment; cool represents "an alternative set of values" (Pountain \& Robbins, 2000, p. 32; cf. also Brown, 2015) in opposition to "toning down" the way one is supposed to as an older woman (Holland, 2004). Pountain and Robbins even point out that cool is no longer solely attached to youth: cool is an attitude that can be adopted across generations. Angela McRobbie also touches upon the 
generational aspect of cool in her discussion of post-feminism. McRobbie claims that the "postfeminist generation's" young female subjects radiate "generationally specific notions of cool" (McRobbie, 2007, p. 34). By contrast, cool provides an attitude "on the edge" when applied to the three female CEOs that opposes the norm of toned-down age appropriateness and also challenges the linking of post-feminist agency with "the cult of youth" (Tasker \& Negra, 2007, p.11).

In contrast to Leona's self-ironic, verbal and media-savvy coolness, Gloria's coolness is connected to her overt, self-conscious bodily display. Finally, with Diane, coolness is attached to bodily control, to an air of superiority and detachment and to a certain masculine leadership style, at the same time that her femininity is emphasised, for example, through her red lips and the tenderness in her love relationship (the true Democrat falls in love with and, subsequently, marries Republican ballistics expert Kurt McVeigh in season five). However, cool on-the-edge-ness is not as prominently attached to her character as to Gloria and Leona; exceptions to this come on the few occasions in which we see her handle a rifle in her spare time. Despite her anti-gun stance, she experiences a physical feeling of empowerment and allure with a gun in her hand and exclaims (season 7, episode 21), "God, I look good with a gun".

By the late 1990s, Mary Russo (1999) had famously coined the term "anachronism" as a conceptualization of the "scandalous" transgressions of age norms. She said about not acting one's age:

\footnotetext{
Thus as I understand it, anachronism is a mistake in a normative systematization of time [...] the risk of anachronism is scandal. Not acting one's age, for instance, is not only inappropriate but dangerous, exposing the female subject, especially, to ridicule, contempt, pity, and scorn - the scandal of anachronism (Russo, 1999, p. 21).
}

The characters in the TV series challenge this whole idea of appropriateness in relation to older women. Diane, Leona and Gloria enjoy being in the limelight and being the centre of attention; they insist on conspicuousness; they make love and fall in love; they make things happen - and their actions, their looks and their authority are never questioned or ridiculed by the series. They are not scandalous; on the contrary, they are cool. Thus, cool's contribution to the look of ageing is the sensibility's opposition to societal norms about age appropriateness and what it means to act one's age. Moreover, cool's edginess and self-consciousness emphasise post-feminist individuality. Hence, I suggest that, as sensibilities, cool and post-feminism together offer an image of agelessness which asks what ageing might look like rather than denying ageing altogether.

\section{Concluding remarks}

The Newsroom, Mozart in the Jungle and The Good Wife cast actresses well over 60 to play CEOs. By placing successful and powerful female characters at the centre as well 
as continually emphasizing their slim figures, the series construct an image of ageing femininity, which counters the previous prevalence in film and television of using younger women to play older characters and constructing older female characters as merely "old".

The series offer a portrayal of the three older women as active, powerful, independent and aware of their sexuality with an added touch of rebellion; hence, I have suggested that they embody what Gill and Scharf (2011) have called a post-feminist sensibility at the same time as they draw attention to a twofold blind spot regarding age in post-feminist theory: First, post-feminism has rarely been discussed with regard to representations of older women (Wearing, 2007, is an exception here). Second, post-feminism has been understood as belonging to a generational set of practices in opposition to second-wave feminism, which is constructed as old-fashioned, even aged - just like the old feminists themselves.

By contrast, however, it could be argued that the series' post-feminist agelessness (the slim, youthful to-be-looked-at-ness, the lack of references to ageing, the powerful societal positions, the individualised agency including the extra-textual gossip about the youthfulness of the actresses) epitomises a contemporary version of ageism in representations of older women, that of a norm of agelessness. Molly Andrews (1999) wrote passionately about agelessness as the new ageism in the late 1990s. She argued that agelessness not only hides old age but also pretends that we never really age (the same criticism is directed towards third-age representations covering up deep old age). Yet, she does not reflect upon the fact that this criticism presupposes that ageing results in a certain look at a certain age and should, therefore, be represented in a particular way.

The parallel to Russo's notion of scandalous anachronism is age appropriateness, a culturally-induced norm of acting and looking one's age as an older person. However, it is implied in both terms that ageing involves "natural" and, therefore, completely similar bodily changes with which one should comply and with which media representations should accord; concealing or misrepresenting these characteristics should be regarded as practicing ageism. Probably, a minority of women over 60 would recognize themselves in Gloria, Leona and Diane, whose slim bodies and prosperous careers may be regarded as fantasy projections for older women, whose lives are very far from the privileged ones depicted here - even though the series are targeted at affluent and hip groups. The series could be criticised for not mirroring older women realistically. Still, the three characters present an alternative image of "successful ageing" for women - an image of continuously fulfilling work instead of retirement and leisure - and remind us that, today, ageing does not equal toning-down and invisibility but appears in many different guises that do not subscribe to the decline discourse (cf. Lips \& Hastings, 2012). Despite the lack of discussion of age in the series, the women are constituted in opposition to established notions of what age appropriateness means. The three series offer, I would claim, representations of "an ageing that is not "old", "de-gendered", "neutralised", "unproductive" or "sexless"'" (Gilleard \& Higgs, 2013, p. 45). 
A youthful, slim body and a concomitant sense of self-confidence seem to be the precondition for the powerful ageing female to come across as trustworthy CEO, as well as for her embodiment of a post-feminist sensibility. Hence, I have suggested that the ageing female CEOs in these three series embody a post-feminist agelessness in which ageing femininity is empowered and made visible. In addition, I have proposed that the cool sensibility gives an edginess to the characters, which supports the idea that agelessness is not merely to be considered a new norm of age appropriateness. In the three series, post-feminist agelessness stages ageing simultaneously as the effacement of the idea of "looking one's age" and as an anti-sentimental ageing sensibility on the edge. In contrast to Kathleen Woodward's idea of "the youthful structure of the look", which either excludes ageing women from the visual field or constructs an overdetermined image of old age, the cool sensibility with which the bodies of Gloria, Leona and Diana are imbued may be regarded as playfully mocking the youthful structure of the look. The cool look of ageing looks back, so to speak. If it is regarded this way, the representations of the older woman as shapely CEOs challenge prejudices about ageing as an accelerating decline.

On one hand, therefore, the fact that age is not tackled as an issue at all in the series can be regarded as merely repeating the denial of ageing once again. On the other hand, the series call attention to the fact that "age appropriateness" can be seen to come in many forms, ultimately problematizing the very concept of "age appropriateness 2 . The series' edgy look of ageing, the bodily to-be-looked-at-ness, the display of sexual allure, power and independence and the construction of self-ironic coolness may open up a wider spectrum of visibilities for older women to occupy in popular culture.

\section{References}

Andrews, M. (1999). The seductiveness of agelessness. Ageing and Society, 19, 301-318.

Bardo, A. R. (2014). Age and gender in film and television: The case of Huong Hoang. In C. L. Harrington et al. (Eds.), Aging, media, and culture (pp. 51-63). Lanham: Lexington Books.

Barrett, A. E., Raphael, A. \& Gundersson, J. (2014). Reflections of old age, constructions of aging selves: Drawing links between media images and views of aging. In C. L. Harrington et al. (Eds.), Aging, media, and culture (pp. 39-51). Lanham: Lexington Books.

Baumann, S. \& de Laat, K. (2012). Socially defunct: A comparative analysis of the underrepresentation of older women in advertising. Poetics, 40, 514-541.

Brown, V. (2015). Cool Shades. The History and Meaning of Sunglasses. London: Bloomsbury Academic.

Clarke, L. H. \& Griffin, M. (2008). Visible and invisible ageing: Beauty work as a response to ageism. Aging \& Society, 28, 653-674.

Clarke, L. H. (2011). Facing age: Women growing older in anti-aging culture. Lanham: Rowman \& Littlefield Publishers.

Dolan, J. (2013). Firm and hard: Stardom, gender and the troubling embodiment of "successful aging". In J. I. Prieto-Arranz et al. (Eds.), De-centring cultural studies: Past, present and future of popular culture (pp. 217-247). Newcastle upon Tyne: Cambridge Scholars Publishing. 
Eagly, A. H. \& Carli, L. L. (2003). The female leadership advantage: An evaluation of the evidence. The Leadership Quarterly, 14, 807-834.

Etcoff, N. (1999). Survival of the prettiest. New York: Anchor Books.

Fairclough, K. (2012). Nothing less than perfect: Female celebrity, ageing and hyper-scrutiny in the gossip industry. Celebrity Studies, 3(1), 90-103.

Garber, M. (2016). The Good Wife: Florrick v. the Sisterhood, The Atlantic, May 9, 2016.

Gerbner, G., Gross, L., Signorielli, N. \& Morgan, M. (1980). Aging with television: Images on television drama and conceptions of social reality. Journal of Communication, 30(1), 37-48.

Gill, R. (2007). Postfeminist media culture. Elements of a sensibility. European Journal of Cultural Studies, 10(2), 147-166.

Gill, R., \& Scharf, C. (2011). Introduction. In R. Gill \& C. Scharff (Eds.), New femininities: Postfeminism, neoliberalism and subjectivity (pp. 1-21). London: Palgrave MacMillan.

Gilleard, C. \& Higgs, P. (2000). Cultures of ageing: Self, citizen and the body. Edinburgh: Pearson Education Limited.

Gilleard, C. \& Higgs, P. (2013). Ageing, corporeality and embodiment. London: Anthem Press.

Gornick, W. (1983). Women in science. New York: Simon \& Schuster Inc.

Gwynne, J. \& Muller, N. (2013). Introduction: Postfeminism and contemporary Hollywood cinema. In J. Gwynne \& N. Muller (Eds.), Postfeminism and contemporary Hollywood cinema. Basingstoke: Palgrave Macmillan.

Higgs, P. \& Gilleard, C. (2006). Departing the margins: Social class and later life in a second modernity. Journal of Sociology, 42(3), 219-241.

Holland, S. (2004). Alternative femininities: Body, age and identity. Oxford: Berg.

Hua, J. (2009). “Gucci geishas" and post-feminism. Women's Studies in Communication, 32(1), 63-88.

Jermyn, D. \& Holmes, S. (2015). Introduction: A timely intervention - unravelling the gender/age/celebrity matrix. In D. Jermyn \& S. Holmes (Eds.), Women, celebrity \& cultures of ageing: Freeze frame (pp. 1-11). Basingstoke: Palgrave Macmillan.

Jerslev, A. (2010). "Rarely a dose of pure truth". Celebritysladder som medieret kommunikationsform. Nordicom Information, 32(1), 23-46.

Jerslev, A. (2017). The elderly female face in beauty and fashion ads: Joan Didion for Céline. European Journal of Cultural Studies, pre-published online ahead of print, DOI: 10.1177/1367549417708436.

Katz, S. (2009). Cultural aging: Life course, lifestyle and senior worlds. North Your: University of Toronto Press.

Katz, S. \& Calasanti, T. (2015). Critical perspectives on successful aging: Does it "appeal more than it illuminates"? The Gerontologist, 55(1), 26-33.

Lauzen, M. M. (2016). It's a man's (celluloid) world: Portrayals of female characters in the top 100 films of 2015. Centre for the Study of Women in Television and Film. Retrieved from http://womenintvfilm. sdsu.edu/files/2015_Its_a_Mans_Celluloid_World_Report.pdf.

Lauzen, M. M. \& Dozier, D. M. (2005). Maintaining the double standard: Portrayals of age and gender in popular films. Sex Roles, 52(7/8), 437-446.

Lauzen, M. M. Dozier, D. M., \& Rayes, B. (2007). From adultescents to zoomers: An examination of age and gender in prime-time television. Communication Quarterly, 55(3), 343-357.

Lips, H. M., \& Hastings, S. L. (2012). Competing discourses for older women: Agency/leadership vs. disengagement/retirement. Women \& Therapy, 35(3-4), 145-164.

Marshall, B. L. \& Rahman, M. (2014). Celebrity, ageing and the construction of 'third age' identities. International Journal of Cultural Studies, 18(6), 577-593. 
McRobbie, A. (2007). Postfeminism and popular culture: Bridget Jones and the new gender regime. In Y. Tasker \& D. Negra (Eds.), Interrogating postfeminism. gender and the politics of popular culture (pp. 27-40). Durham: Duke University Press.

McRobbie, A. (2009). The aftermath of feminism: Gender, culture and social change. Los Angeles: Sage Publications.

Pountain, D. \& Robbins, D. (2000) Cool rules: Anatomy of an attitude. London: Reaktion Books.

Rowe, J. \& Kahn, R. (1997). Succesful ageing. The Gerontologist 37(4), 433-440.

Russo, M. (1999). Aging and the scandal of anachronism. In K. Woodward (Ed.), Figuring age: Women, bodies, generations (pp. 20-34). Bloomington: Indiana University Press.

Sandvoss, C. (2014). Afterword: A view from media studies. In C. L. Harrington et al. (Eds.), Aging, media, and culture (pp. 211-217). Lanham: Lexington Books.

Signorielli, N. \& Bacue, A. (1999). Recognition and respect: A content analysis of prime-time television characters across three decades. Sex Roles, 40(7/8), 527-544.

Signorielli, N. (2001). Aging on television: The picture in the Nineties. Generations, 25(3), 34-38.

Signorielli, N. (2004). Aging on television: Messages relating to gender, race and occupation in prime time. Journal of Broadcasting and Electronic Media, 48(2), 279-301.

Tasker, Y. \& Negra, D. (2007). Introduction: Feminist politics and postfeminist culture. In Y. Tasker \& D. Negra (Eds.), Interrogating postfeminism. gender and the politics of popular culture (pp. 1-27). Durham: Duke University Press.

Ticknell, E. (2011). Scourging the abject body: Ten Years Younger and fragmented femininity under neoliberalism. In R. Gill \& C. Scharff (Eds.), New femininities. Postfeminism, neoliberalism and subjectivity (pp. 83-99). London: Palgrave MacMillan.

Twigg, J. (2013). Fashion and age: Dress, the body and later life. London: Bloomsbury

Van den Bulck, H. (2014). Growing old in celebrity culture. In C. L. Harrington et al. (Eds.), Aging, media, and culture (pp. 65-77). Lanham: Lexington Books.

Vecchio, R. P. (2002). Leadership and gender advantage. The Leadership Quarterly 13, 643-671.

Whelehan, I. (1995). Modern feminist thought. from the second wave to 'post-feminism'. New York: New York University Press.

Whelehan, I. (2013). Ageing appropriately: Postfeminist discourses of ageing in contemporary Hollywood. In J. Gwynne \& N. Muller (Eds.), Postfeminism and contemporary Hollywood cinema (pp. 78-99). Basingstoke: Palgrave Macmillan.

Wearing, S. (2007). Subjects of rejuvenation: Aging in postfeminist culture. In Y. Tasker \& D. Negra (Eds.), Interrogating postfeminism. gender and the politics of popular culture (pp. 277-311). Durham: Duke University Press.

Williams, A., Wadleigh, P. M. \& Ylänne, V. (2010). Images of older people in UK magazine advertising: Towards a typology. International Journal of Aging and Human Development, 71(2), 83-114.

Women's Media Center (2014). The status of women in the US media 2014. Retrieved from http://www. womensmediacenter.com.

Women's Media Center (2015). The status of women in the US media 2015. Retrieved from http://www. womensmediacenter.com.

Woodward, K. (2006). Performing age, performing gender. NWSA Journal, 18(1), 162-189.

\section{Notes}

1 The Good Wife is targeted at an "upscale female audience" (http://deadline.com/2012/06/emmys-thegood-wife-creators-aim-to-remain-true-to-their-characters-281144/). Mozart in the Jungle targeted at 
a "niche audience of twenty- and thirty-somethings" ("for hipsters") (http://www.immersiononline. net/television/Mozart-in-the-Jungle-Season-One-review); finally, The Newsroom is generally targeted at HBO's 24-49 educated demographics.

2 An example of this is the US cable channel FX's continuous efforts to widen their 18-49 male demographic (which was so successfully reached with The Shield); the channel tried to target a female audience less successfully with the remake of The Bridge (2013-2014) and more successfully with American Horror Story (2011- ), which has starred a range of prominent female actresses - among them, Jessica Lange (b. 1949), Kathy Bates (b. 1948) and Sarah Paulson (b. 1974).

3 Hence, The Good Wife counters the stereotype that "women who are perceived as ambitious and interested in gaining power are viewed as peculiar, unlikeable, and lacking the essential communal orientation associated with femininity" (Lips \& Hastings, 2012, p. 149). It also counters differences in appearance between younger and older female scientists, observed by Vivian Gornick in 1980 (Gornick, 1983, p. 119-121.

4 http://www.plasticsurgerytalks.com/christine-baranski-plastic-surgery/ (posted April 25, 2015, retrieved October 22, 2016).

5 http://celebritypost.net/christine-baranski-plastic-surgery/ (posted June 15, 2015, retrieved October 22, 2016).

6 http://news.makemeheal.com/celebrity-plastic-surgery/bernadette-peters-plastic-surgery/445 (posted on June 27, 2008, retrieved October 22, 2016).

7 http://www.mindblowingworld.com/bernadette-peters-plastic-surgery/ (posted December, 2014, retrieved October 22, 2016).

8 Cited from Huffington Post, April 22, 2010 (accessed at http://www.huffingtonpost.com/2010/02/20/ jane-fondas-plastic-surge_n_469938.html)

Anne Jerselv

Professor, Department of Media, Cognition and Communication

University of Copenhagen

jerslev@hum.ku.dk 